\title{
EFEKTIVITAS EKSTRAK BUNGA JANTAN SUKUN (Artocarpus altis) TERHADAP PERTUMBUHAN Streptococcus mutans
}

\author{
Effectiveness Of Breadfruit Male Flower Extract (Artocarpus Altis) On The Growth Of Streptococcus \\ mutans
}

\author{
Muhdar Latif*, Suherman B, Dewi Isnaeni, Zulkifli
}

Fakultas Farmasi Universitas Indonesia Timur

*Email : muhdar1981@gmail.com

DOI: https://doi.org/10.32382/mf.v15i2.1263

\begin{abstract}
Breadfruit male flower (Artocarpus altilis) contains compounds with the ability to prevent the growth of Streptococcus mutans. This research, therefore, aims to determine the effect of breadfruit male flower in inhibiting Streptococcus mutans using ethanol solvent in concentrations of 1\%, 2\%, and 3\% w/v. The results showed that the average inhibition zone of male breadfruit extract concentration was $1 \% \mathrm{w} / \mathrm{v}$, $2 \% \mathrm{w} / \mathrm{v}, 3 \% \mathrm{w} / \mathrm{v}$, and amoxicillin at $14.2 \mathrm{~mm}, 21.3 \mathrm{~mm}, 22.8 \mathrm{~mm}$ and $38.2 \mathrm{~mm}$, respectively. However, statistical analysis showed that the breadfruit male flower extract at a concentration of $1 \% \mathrm{w} / \mathrm{v}, 2 \% \mathrm{w} / \mathrm{v}$ and $3 \% \mathrm{w} / \mathrm{v}$ had a significant effect below amoxicillin $(p<0,05)$
\end{abstract}

Keywords: Breadfruit Male Flower Extract (Artocarpus altis); Streptococcus mutans

\begin{abstract}
ABSTRAK
Bunga Jantan Sukun (Artocarpus altilis) mengandung senyawa yang diduga dapat mencegah pertumbuhan Streptococcus mutans penyebab karies gigi. Penelitian ini bertujuan untuk mengetahui pengaruh Ekstrak Bunga Jantan Sukun (Artocarpus altilis) dalam menghambat Streptococcus mutans penyebab karies gigi. Sampel penelitian ini adalah bunga jantan sukun yang diekstraksi secara maserasi dengan pelarut etanol. Ekstrak bunga jantan sukun masing-masing dibuat dalam konsentrasi $1 \%, 2 \%$ dan $3 \% \mathrm{~b} / \mathrm{v}$. Hasil penelitian menunjukkan rata-rata zona hambat ekstrak bunga jantan sukun konsentrasi $1 \% \mathrm{~b} / \mathrm{v}$ sebesar 14,2 mm, 2\%b/v sebesar 21,3 mm, konsentrasi 3\%b/v sebesar 22,8 mm dan amoxicillin sebesar $38,2 \mathrm{~mm}$. Hasil analisis statistika menunjukkan ekastrak Bunga Jantan Sukun (Artocarpus altilis) pada konsentrasi $1 \% \mathrm{~b} / \mathrm{v}, 2 \% \mathrm{~b} / \mathrm{v}$ dan $3 \% \mathrm{~b} / \mathrm{v}$ memberikan efek signifikan dalam menghambat Streptococcus mutans namun efektivitasnya masih dibawah amoxicillin $(\mathrm{p}<0,05)$
\end{abstract}

Kata kunci : Ekstrak Bunga Jantan Sukun (Artocarpus altis); Streptococcus mutans

\section{PENDAHULUAN}

Kesehatan mulut merupakan hal penting untuk kesehatan secara umum dan kualitas hidup. Kesehatan mulut berarti terbebas dari kanker tenggorokan, infeksi luka pada mulut, penyakit gusi, kerusakan gigi, kehilangan gigi, dan penyakit lainnya, sehingga terjadi gangguan yang membatasi dalam menggigit, mengunyah, tersenyum, berbicara dan kesejahteraan psikososial. (Widayati, 2014)

Karies gigi atau gigi berlubang masih menjadi permasalahan utama dalam dunia kedokteran gigi baik di Indonesia maupun di seluruh dunia. Karies telah terjadi sejak zaman prasejarah dan masih menjadi salah satu penyakit gigi yang cukup tinggi sampai dengan saat ini. (Sulistiadi, 2007)
Berdasarkan survei kesehatan gigi yang dilakukan oleh Direktorat Kesehatan Gigi Departemen Kesehatan RI pada tahun 1994, ternyata selama PELITA ke-V jumlah masyarakat yang berkunjung maupun pasien yang dirujuk ke rumah sakit karena menderita penyakit gigi dan mulut akibat karies gigi menduduki jumlah terbesar yaitu 53,05\%, sedangkan penyakit periodontal menduduki tempat kedua yaitu sebanyak 28,32\%. (Sabir, 2005)

Karies gigi merupakan suatu penyakit yang dapat menular dan terutama mengenai jaringan keras gigi sehingga terjadi kerusakan jaringan keras setempat. Proses terjadinya kerusakan pada jaringan keras gigi melalui suatu 
reaksi kimiawi oleh bakteri, dimulai dengan proses kerusakan pada bagian anorganik, kemudian berlanjut pada organik. (Sabir, 2005).

Karies gigi adalah suatu penyakit yang disebabkan oleh adanya interaksi antara bakteri plak, diet, dan gigi. Tidak diragukan lagi bahwa tanpa adanya plak maka tidak akan timbul karies. Banyak yang dapat dilakukan untuk mencegah karies, dengan mengetahui penyebabnya merupakan hal penting agar mengerti cara melakukan pencegahannya. Pencegahan karies dan penyakit periodontal dengan melakukan peningkatan kesehatan gigi telah menjadi tujuan utama dalam dunia kedokteran gigi, sejak diketahui plak gigi merupakan faktor yang mendominasi penyebab hilangnya gigi oleh karna karies dan penyakit periodontal. Salah satu cara pencegahan karies adalah mengusahakan agar pembentukan plak pada permukaan gigi dapat dibatasi baik dengan cara mencegah pembentukannya atau dengan pembersihan plak secara teratur. Pengendalian plak dapat dilakukan dengan cara pembersihan plak mekanis dan kemungkinan penggunaan bahan anti kuman terutama untuk menekan bakteri Streptococcus mutans. Menyikat gigi membantu kontrol plak dan merupakan langkah awal untuk mengontrol karies dan penyakit periodontal baik untuk individu maupun populasi. (Pratiwi, 2005) Streptococcus mutans merupakan bakteri utama penyebab karies gigi, bakteri ini mampu melekat pada permukaan gigi ; memproduksi enzim glukurinol transferase. Enzim tersebut menghasilkan glukan yang tidak larut dalam air dan berperan dalam menimbulkan plak dan koloni pada permukaan gigi. (Zaenab $\mathrm{dkk}, 2004)$. Telah banyak dilakukan penelitian dan pemanfaat bahan alam yang digunakan sebagai obat, selain itu jarang menimbulkan efek samping yang merugikan dibandingkan obat yang terbuat dari bahan sintetis. Ada beberapa jenis tanaman yang diduga berkhasiat mengatasi karies gigi, salah satunya bunga Sukun (Artocarpus altilis).

Sukun (Artocarpus altilis) merupakan tanaman yang penyebarannya merata karna dapat tumbuh hampir diseluruh indonesia. Tanaman ini menghasilkan bunga betina (buah) biasanya digunakan sebagai bahan pangan karena daging buahnya tebal sehingga dimakan. Sedangkan pada bunga jantan tidak terjadi penebalan daging buah dan pada saatnya akan ke tanah dan tidak bisa dimakan. Berdasarkan pengujian di Laboratorium Biokimia FMIPA Universitas Mulawarman bunga sukun jantan mengandung flavonoid, dimana flavonoid ini sendiri memiliki aktivitas sebagai antibakteri. (Lumowa, 2013 \& Sabir, 2005)
Flavonoid merupakan senyawa yang mudah larut dalam senyawa polar seperti etanol, butanol, dan aseton. Flavonoid golongan terbesar dari senyawa fenol, senyawa fenol dapat mengganggu pertumbuhan bakteri Streptococcus mutans. Mekanisme kerja senyawa flavonoid dengan cara mendenaturasi protein sel bakteri dan merusak membran sel. (Liantari, 2014 \& Siagian, Dkk 2015)

Berdasarkan uraian diatas maka yang menjadi permasalahan dalam penelitian ini adalah bagaimana efektivitas ekstrak bunga Sukun jantan (Artocarpus altilis) dalam menghambat pertumbuhan Streptococcus mutans penyebab karies gigi ?

Tujuan dilakukannya penelitian ini adalah untuk mengetahui pengaruh konsentrasi terhadap ekstrak bunga Jantan Sukun (Artocarpus altilis) dalam menghambat pertumbuhan Streptococcus mutans penyebab karies gigi.

Manfaat penelitian ini adalah untuk mendapatkan data ilmiah tentang bahan alam yang dapat dijadikan sebagai bahan pertimbangan bagi bahan industri obat atau obat tradisional.

\section{METODE}

\section{Jenis dan Desain Penelitian}

Jenis penelitian ini adalah penelitian menggunakan rancangan eksperimen di Laboratorium, dengan Desain penelitian untuk mengetahui dan menentukan besarnya daya hambat dari ekstrak bunga Sukun (Artocarpus altilis) terhadap Streptococcus mutans.

\section{Waktu dan Tempat Penelitian}

Telah dilakukan penelitian pada bulan November 2017 di Laboratorium Fitokimia dan Mikrobiologi Farmasi, Fakultas farmasi Universitas Indonesia Timur.

\section{Alat dan Bahan yang Digunakan}

Alat yang digunakan adalah Autoklaf, aluminium foil, batang pengaduk. Bunsen, chamber, cawan petri, corong kaca, erlenmeyer, gegep, gelas kimia, gunting, karet, kertas saring, kertas karkil, label, lap halus, lampu UV, lemari es, masker, mistar, oven, pipet tetes, seperangkat alat maserasi, rotavapor, timbangan analitik, termometer, vial, waterbath. Bahan yang digunakan adalah Aquadest, aluminium foil, biakan Streptococcus mutans, ekstrak bunga sukun jantan, etanol 96\%, kapas, Medium Nutrien Agar (NA), Medium Mueller Hinton Agar (MHA), Nacl 0,9\%, Na.CMC $1 \%$. 


\section{Pengambilan bahan uji}

Bahan uji yang akan digunakan dalam penelitian ini adalah tanaman Sukun yang diambil di Desa Wiwitan, Kec. Lamasi, Kabupaten Luwu.

\section{Pengolahan bahan uji}

Bahan uji yang digunakan dalam penelitian ini adalah tanaman bunga Sukun jantan, dimana bunga Sukun yang telah dikumpulkan disortasi, dicuci dengan air mengalir kemudian dikeringkan dengan cara diangin-anginkan pada tempat yang tidak terkena sinar matahari langsung.

\section{Pembuatan ekstrak bunga Sukun dengan maserasi \\ Tanaman bunga Sukun jantan yang} telah dikeringkan kemudian, masing-masing ditimbang 250 gram kemudian dimasukkan dalam bejana maserasi ditambahkan etanol hingga terendam sempurna. Bejana lalu ditutup, di diamkan di tempat gelap selama 5 hari sambil sering diaduk-aduk, kemudian disaring. Ekstrak yang diperoleh dikumpulkan kemudian diuapkan dengan rotavapor dilanjutkan diatas penangas air sehingga diperoleh ekstrak kental.

\section{Pembuatan Larutan}

Larutan Uji dibuat denga konsentrasi $1 \% \mathrm{~b} / \mathrm{v} ; 2 \% \mathrm{~b} / \mathrm{v}$; dan $3 \% \mathrm{~b} / \mathrm{v}$; dalam larutan Na.CMC 1\%. Larutan Na CMC $1 \%$ sebagai konrol negatif dan Larutan kontrol positif (amoxycillin) $30 \mathrm{bpj}$.

\section{Pengujian Aktivitas}

Medium MHA sebanyak $5 \mathrm{ml}$ dituang secara aseptik kedalam cawan petri steril, lalu ditambahkan $1 \mathrm{ml}$ suspensi Streptococcus mutans lalu dihomogenkan dan dibiarkan memadat, kemudian paperdisk dicelupkan kedalam sampel uji dan diletakkan pada media, selanjutnya di inkubasi selama 1 x 24 jam.

\section{PENGAMATAN DAN PENGUKURAN DIAMETER HAMBATAN}

Pengamatan dan pengukuran hambatan dilakukan setelah masa inkubasi 1 x 24 jam pada suhu $37^{\circ} \mathrm{C}$ dengan menggunakan jangka sorong.

\section{PENGUMPULAN DATA DAN ANALISIS DATA}

Data dari hasil penelitian yang dikumpulkan dan dilakukan analisis data secara statistik menggunakan metode ANAVA dan uji rentang Newman-keuls.

\section{HASIL}

Dari hasil penelitian yang diperoleh berupa pengukuran diameter zona hambat Ekstrak Bunga Jantan Sukun (Artocarpus altilis) yang berasal dari Kabupaten Luwu terhadap Streptococcus mutans dengan masa inkubasi 1 X 24 jam pada suhu $37^{\circ} \mathrm{C}$. Hasil penelitian selengkapnya dapat dilihat pada tabel berikut :

Tabel 1. Hasil Pengukuran Diameter Hambatan (mm) Ekstrak Bunga Jantan Sukun (Artocarpus altilis) Terhadap Streptococcus mutans dengan masa inkubasi 1 X 24 jam pada suhu $37^{\circ} \mathrm{C}$.

Diameter Zona Hambatan (mm) Inkubasi 1 X 24 Jam

\begin{tabular}{|c|c|c|c|c|c|}
\hline \multirow{3}{*}{ Bakteri Uji } & \multirow{2}{*}{\multicolumn{3}{|c|}{$\begin{array}{c}\text { Konsentarsi Ekastrak } \\
\text { Bunga Jantan Sukun } \\
\text { (Artocarpus altilis) }\end{array}$}} & \multirow{3}{*}{$\begin{array}{l}\text { Kontrol Positif } \\
\text { (Amoxicillin) }\end{array}$} & \multirow{3}{*}{$\begin{array}{l}\text { Kontrol Negatif } \\
(\text { Na.CMC 1\%) }\end{array}$} \\
\hline & & & & & \\
\hline & $1 \%$ & $2 \%$ & $3 \%$ & & \\
\hline \multirow{3}{*}{$\begin{array}{c}\text { Streptococcus } \\
\text { mutans }\end{array}$} & 13,3 & 20,7 & 22,5 & 37,5 & 6 \\
\hline & 14,8 & 21,5 & 23,5 & 38,5 & 6 \\
\hline & 14,5 & 21,9 & 22,6 & 38,7 & 6 \\
\hline Jumlah & 42,6 & 61,4 & 68,6 & 114,7 & 18 \\
\hline Rata-rata & 14,2 & 21,3 & 22,5 & 38,2 & 6 \\
\hline
\end{tabular}




\section{PEMBAHASAN}

Penelitian ini dilakukan dengan menggunakan ekstrak bunga jantan sukun (Artocarpus altilis) sebagai bahan utama untuk melihat efektivitas hambatan terhadap Streptococcus mutans dengan menggunakan metode difusi. Metode ini digunakan untuk menentukan daya hambat atau aktivitas agen antimikroba. Prinsip kerja metode ini yaitu piringan/cawan petri yang berisi agen antimikroba diletakkan pada media Agar yang telah ditanami mikroorganisme, yang nantinya akan berdifusi pada media Agar tersebut. Terbentuknya area jernih mengindikasikan adanya hambatan pertumbuhan mikroorganisme oleh agen antimikroba pada permukaan media Agar (Pratiwi, 2010).

Pada penelitian ini digunakan ekstraksi secara maserasi. Jenis ekstraksi ini digunakan karena merupakan cara penyarian yang sederhana. Bahan yang digunakan pada ekstraksi ini yaitu bahan yang bertekstur lunak seperti bunga. Maserasi dilakukan dengan merendam bahan uji dalam cairan penyari. Adapun kontrol positif yang digunakan yaitu Amoxicillin, Amoxicillin merupakan obat antibiotik yang digunakan untuk mengatasi infeksi yang disebabkan oleh bakteri, dan Na.CMC $1 \%$ sebagai kontrol negatif, dimana Na.CMC $1 \%$ sebagai pelarut bahan uji. Larutan kontrol ini digunakan untuk melihat ada tidaknya efek yang ditimbulkan berdasarkan zona hambatan yang terbentuk sehingga dapat dibandingkan dengan zona hambatan dari bahan uji yang digunakan.

Dari data hasil penelitian yang dilakukan, diketahui bahwa ekstrak bunga jantan Sukun (Artocarpus altilis) dapat bersifat sebagai antibakteri yang mampu menghambat pertumbuhan Streptococcus mutans. Hal ini dibuktikan dengan adanya zona hambatan yang terbentuk di sekitar paper disk yang berwarna bening.

Konsentrasi yang digunakan untuk ekstrak bunga jantan Sukun yaitu 1\% b/v, 2\% $\mathrm{b} / \mathrm{v}$, dan $3 \% \mathrm{~b} / \mathrm{v}$ dengan masa Inkubasi $1 \times 24$ Jam, ekstrak bunga jantan Sukun (Artocarpus altilis) menunjukkan adanya zona hambat yang bervariasi seiring dengan kenaikan konsentrasi, untuk rata-rata konsentrasi $1 \% \mathrm{~b} / \mathrm{v}(14,2 \mathrm{~mm})$, $2 \% \mathrm{~b} / \mathrm{v}(21,3 \mathrm{~mm}), 3 \% \mathrm{~b} / \mathrm{v}(22,8 \mathrm{~mm})$. Dilihat dari diameter zona hambatnya konsentrasi $3 \%$ $\mathrm{b} / \mathrm{v}$ yang lebih menghambat, karena pada konsentrasi ini zat yang terkandung dalam tanaman bunga jantan Sukun lebih banyak dari lainnya, sedangkan kontol positif (amoxicillin) masih lebih besar efeknya dibandingkan dengan beberapa konsentrasi dari ekstrak Bunga Jantan Sukun dengan rata-rata zona hambat yang didapatkan sebesar $(38,2 \mathrm{~mm})$, sedangkan kontrol negatif Na.CMC (6 mm).

Hal tersebut di atas menunjukkan bahwa dari ekstrak bunga jantan Sukun (Artocarpus altilis), memiliki daya hambat sebagai antibakteri yang dapat menghambat pertumbuhan Streptococcus mutans, dilihat dari zona hambatnya, konsentrasi 3\% lebih tinggi zona hambatnya dibandingkan dengan konsentrasi $1 \%$ dan 2\%. Pada konsentrasi 3\% $\mathrm{b} / \mathrm{v}$ memberikan efek paling efektif terhadap pertumbuhan Streptococcus mutans. Bahan aktif yang berkhasiat sebagai antibakteri yang terkandung didalam bunga jantan Sukun mengandung senyawa flavonoid dan tanin.

Mekanisme aksi dari Flavanoid terhadap bakteri dengan cara membentuk senyawa kompleks terhadap protein extraseluler yang mengganggu keutuhan membran sel bakteri. Mekanisme kerjanya dengan cara mendenaturasi protein sel bakteri dan merusak membran sel tanpa dapat diperbaiki lagi.

Mekanisme kerja tannin sebagai antibakteri adalah menghambat enzim reverse transkriptase dan DNA topoisomerase sehingga sel bakteri tidak dapat terbentuk. Tanin memiliki aktivitas antibakteri yang berhubungan dengan kemampuannya untuk mengaktifkan enzim, dan menggangu transport protein pada lapisan dalam sel.

Dari hasil statistika menggunakan metode ANAVA menunjukkan bahwa ekstrak Bunga Jantan Sukun (Artocarpus altilis) dan amoxicillin sebagai pembanding, pada konsentrasi $1 \% \mathrm{~b} / \mathrm{v}, 2 \% \mathrm{~b} / \mathrm{v}$, dan $3 \% \mathrm{~b} / \mathrm{v}$ dengan masa inkubasi 1 X 24 jam memberikan zona hambat yang sangat signifikan atau sangat berbeda nyata terhadap pertumbuhan Streptococcus mutans, dimana zona hambat menunjukan bahwa nilai $F_{\text {hitung sebesar }}$ $(1244,38 * *)$ lebih besar dari pada $\mathrm{F}_{\text {tabel }}$ pada taraf $0,05(3,48)$ dan pada taraf $0,01(5,99)$.

\section{KESIMPULAN}

Bunga Jantan Sukun (Artocarpus altilis) pada konsentrasi $1 \% \quad b / v, 2 \% \quad b / v$ dan $3 \% \quad b / v$ memberikan efek signifikan dalam menghambat Streptococcus mutans namun efektivitasnya masih dibawah amoxicillin $(\mathrm{p}<0,05)$

\section{DAFTAR PUSTAKA}

Armigon, S., \& Caufiled, P.W. 2011. Distribution of putative virulence genes in Streptococcus mutans strain does not corrolate with caries experience. Jurnal of clinical microbiology. 
Dalimartha, S.2003. Atlas Tumbuhan Obat Indonesi. Jilid 3. Jakart; Puapa swara.

Hargono, Djoko, Dkk. 2012. Sediaan Galenika. Indomedia. Makassar

Heyne, K. 1987. Tumbuhan Berguna Indonesia II (diterjemahkan oleh badan litbang kehutanan Jakarta). Jakarta; penerbit yayasan sarana wana jaya. 670-672.

Lamowa, Sonja V.T., 2013. Pengaruh MAT serbukbunga sukun (Artocarpus altalitis) sebagai isi ulang nati nyamuk elektrik terhadap kematian nyamuk Aedes aegepty L. (penunjang mata kuliah dermatologi). Samarinda; diakses tanggal 22 september 2017

Liantari, Septiani Diah. 2014. Effect of Wuluh starfruit leaf extract for Streptococcus mutans growth. Lampung

Nugraha, Widya A., 2008. Streptococcus mutans. Yogyakarta; Diakses pada tanggal 25 september 2017.

Pratiwi, Rini. 2005. Perbedaan daya hambat terhadap Streptococcus mutans dari beberapa pasta gigi yang mengandung herbal. Diakses pada tanggla 25 september 2017

Sabir, Ardo. 2005. Aktivitas antibakteri flavonoid propolis trigona sp terhadap bakteri streptococcus mutans (in vitro). Makassar

Siagian, Dkk. 2015. Uji efektivitas ekstrak daun Binahong (Anredera cordifolia steenis) terhadap pertumbuhan Streptococcus mutans secara invitro.

Umar, A, Dkk., 2007. Ekstrak total senyawa flavonoid dan fitosterol daun sukun (Artocarpus altalitis) sebagai kardio vaskuler dan teknik produksinya.

Vinogardof, A, M., Wiston, M., Rupp, C,J., \& Stoodly, P. 2004. Rheology of biofilms formal from the dental plages pathogen Streptococcus mutans. Biofilm
Sulistiadi, Wahyu. 2007. Pengaruh pengunyahan permen karet dengan pemanis Xylitol terhadap penurunan resiko karies gigi.

Widayati, Nur. 2014. Faktor yang berhubungan dengan karies gigi pada anak usia 4-6 tahun.

Zaenab, Dkk. 2004. Uji antibakteri siwak (Salvadora persica Lin). Terhadap Strepotococcus mutans (ATC31982) dan bacteriodes melaninogeni. Diakses pada tanggal 25 september 2017 